\title{
KESESUAIAN PERESEPAN OBAT BPJS BERDASARKAN FORMULARIUM NASIONAL DAN FORMULARIUM RUMAH SAKIT DI RSD IDAMAN BANJARBARU
}

\section{THE SUITABILITY OF PRESCRIBING BPJS DRUGS BASED ON THE NASIONAL FORMULARY AND HOSPITAL FORMULARY IN BANJARBARU IDAMAN HOSPITAL}

\author{
Rahmayanti Fitriah ${ }^{1}$, Mariyana $^{1}$ \\ Sekolah Tinggi Ilmu Kesehatan Borneo Lestari \\ Email : rahmayanti.fitriah@yahoo.com
}

\begin{abstract}
ABSTRAK
Ketidaksesuaian peresepan obat BPJS berdasarkan Formularium Nasional dan Formularium Rumah Sakit sering terjadi. Hal ini menyebabkan adanya keluhan pasien, terutama pasien yang merupakan golongan masyarakat kebawah atau kurang mampu, sedangkan bagi rumah sakit hal tersebuttentu akan mempengaruhi mutu pelayanan bagi pasien BPJS.Penelitian dilakukan di Poliklinik Penyakit Dalam Rumah Sakit Daerah Idaman Kota Banjarbaru untuk mengukur persentase kesesuaian resep dengan formularium nasional dan formularium rumah sakit. Jenis penelitian non eksperimental dan bersifat deskriptif evaluatif non analitik. Pendekatan pengambilan data secara retrospektif. Populasi penelitian adalah seluruh resep yang ditulis dokter poli penyakit dalam untuk pasien BPJS kecuali resep racikan pada bulan April sampai Juni 2018. Data diambil dengan teknik proporsional random sampling dengan tingkat kesalahan $10 \%$, didapatkan sampel sebanyak 100 lembar resep. Analisis data menggunakan rumus persentase kesesuaian peresepan obat BPJS dengan formularium nasional dan formularium rumah sakit. Hasil penelitian diperoleh kesesuaian peresepan obat BPJS berdasarkan Formularium Nasional sebanyak 68 lembar resep atau 68,35\%, dan yang tidak sesuai sebanyak 32 lembar resep atau $31,65 \%$, kesesuaian peresepan obat BPJS berdasarkan Formularium Rumah Sakit sebanyak 87 lembar resep atau $86,11 \%$ dan yang tidak sesuai sebanyak 13 lembar resep atau 13,89\%.
\end{abstract}

Kata Kunci : Peresepan Obat, Pasien BPJS, Formularium Nasional, Formularium Rumah Sakit.

\begin{abstract}
Discrepancies in prescribing BPJS drugs based on the National Formulary and Hospital Formulary often occur. This causes complaints from patients, especially patients who are in the lower class or the poor, while for hospitals it will certainly affect the quality of service for BPJS patients. The study was conducted at the Internal Medicine Polyclinic at the Regional Hospital of the City of Banjarbaru to measure the percentage of the suitability of the prescription with the national formulary and hospital formulary. This type of research is non-experimental and is nonanalytic evaluative descriptive. Retrospective data collection approach. The study population was all prescriptions written by doctors of internal medicine for BPJS patients except for prescription concoctions in April to June 2018. Data were taken by proportional random sampling technique with an error rate of $10 \%$, obtained as many as 100 prescription sheets. Data analysis uses the formula of the suitability of BPJS drug prescribing percentage with national formulary and hospital formulary. The results of the study showed that the suitability of
\end{abstract}


BPJS drugs prescription based on National Formulary were 68 prescription sheets or $68.35 \%$, and 32 pieces were not suitable or $31.65 \%$ prescriptions, the suitability of BPJS prescription drugs based on Hospital Formulary were 87 prescriptions or $86.11 \%$ and 13 appropriate recipes or $13.89 \%$.

Keywords: Drug prescription, BPJS patients, National Formulary, Hospital Formulary.

\section{PENDAHULUAN}

Upaya kesehatan adalah setiap kegiatan untuk memelihara dan meningkatkan kesehatan, bertujuan untuk mewujudkan derajat kesehatan yang optimal bagi masyarakat. Upaya kesehatan diselenggarakan dengan pendekatan pemeliharaan, peningkatan kesehatan (promotif), pencegahan penyakit (preventif), penyembuhan penyakit (kuratif) dan pemulihan kesehatan (rehabilitatif) yang dilaksanakan secara menyeluruh terpadu dan berkesinambungan. Konsep kesatuan upaya kesehatan ini menjadi pedoman dan pegangan bagi semua fasilitas kesehatan di Indonesia termasuk rumah sakit ${ }^{1-3}$

Rumah Sakit adalah institusi pelayanan kesehatan yang menyelenggarakan pelayanan kesehatan perorangan secara paripurna yang menyediakan pelayanan rawat inap, rawat jalan dan gawat darurat. ${ }^{4}$

Pemerintah berkewajiban menyelenggarakan program jaminan kesehatan bagi seluruh rakyat Indonesia. Tujuan diberlakukannya program Jaminan Kesehatan Nasional ini adalah untuk memenuhi kebutuhan kesehatan masyarakat yang layak diberikan kepada setiap orang yang telah membayar iuran atau iurannya dibayar oleh pemerintah. ${ }^{4,5}$

Badan Penyelenggara Jaminan Sosial yang selanjutnya disingkat menjadi BPJS Kesehatan adalah badan hukum yang dibentuk untuk menyelenggarakan program jaminan kesehatan, dimana jaminan tersebut berupa perlindungan kesehatan agar peserta memperoleh manfaat pemeliharaan kesehatan dan perlindungan dalam memenuhi kebutuhan dasar kesehatan yang diberikan kepada setiap orang yang telah membayar iuran dan atau yang dibayarkan oleh pemerintah. Daftar obat-obatan yang telah dituangkan dalam suatu Formularium Nasional yang harus dipatuhi oleh para penulis resep. ${ }^{4-6}$
Formularium Nasional adalah daftar obat yang disusun oleh komite nasional yang ditetapkan oleh Menteri Kesehatan, didasarkan pada bukti ilmiah mutakhir berkhasiat, aman dan dengan harga yang terjangkau yang disediakan serta digunakan sebagai acuan penggunaan obat dalam Jaminan Kesehatan Nasional (JKN). ${ }^{5}$

Formulaium Rumah Sakit adalah buku pedoman yang berisi daftar nama obat generic dan nama dagang yang disediakan oleh rumah sakit yang bersangktan yang dibuat oleh Tim Farmasi dan Terapi (KFT) dan disetujui oleh Tim Medis, telah disahkan melalui keputusan direktur rumah sakit. Pada penelitian yang dilakukan oleh Fitriah, $\mathrm{R}$ menyatakan bahwa penggunaan formularium rumah sakit masih belum mencapai $100 \%{ }^{7}$

Peneliti telah melakukan studi pendahuluan di Instalasi Farmasi RSD Idaman Banjarbaru khusunya pada resep poliklinik penyakit dalam ditemukan permasalahan adanya peresepan obat untuk pasien BPJS menggunakan obat diluar Formularium Nasional (FORNAS) dan Formularium Rumah Sakit(FRS) yang menyebabkan adanya keluhan pasien karena harus membeli obat tersebut padahal pasien merupakan golongan masyarakat kebawah atau kurang mampu, sedangkan bagi rumah sakit hal tersebut akan mempengaruhi mutu pelayanan bagi pasien BPJS.

Tujuan penelitian ini adalah untuk mengetahui persentase kesesuaian peresepan obat pasien BPJS Kesehatandengan Formularium Nasional dan Formularium Rumah Sakit di Poliklinik Penyakit Dalam RSD Idaman Banjarbaru periode April sampai Juni 2018

\section{METODE PENELITIAN}

Jenis penelitian yang digunakan merupakan penelitian deskriptif menggunakan metode observasionaldengan rancangan cross sectional. Metode pengambilan sampel secara retrospektif 
tentang kesesuaian resep pasien BPJS Kesehatan dengan Formularium Nasional dan Formularium Rumah Sakit di Poliklinik Penyakit Dalam RSD Idaman Banjarbaru periode bulan April sampai Juni 2018.

Populasi dalam penelitian ini adalah semua resep pasien BPJS non racikan di Poliklinik Penyakit Dalam RSD Idaman Banjarbaru periode April sampai Juni $2018 . \quad$ Berdasarkan studi pendahuluan diketahui jumlah resep poliklinik penyakit dalam non racikan pada bulan April sampai Juni 2018 adalah 1.145 lembar resep.

Teknik sampling penelitian ini menggunakan metode Simple random sampling dengan cara Proporsional sampling. Penentuan jumlah sampel dari polulasi menggunakan rumus Slovin dengan tingkat kepercayaan 10\% didapat sampel minimal 91,9 dibulatkan menjadi 100 lembar resep, dengan perhitungan proporsional sebagai berikut.

1. Bulan April 2018 ada 394 lembar resep, maka diperoleh sampel sebanyak $=\underline{394} \quad \mathrm{x}$ 100 resep $=34$ resep 1145

2. Bulan Mei 2018 ada 451 lembar resep, maka diperoleh sampel sebanyak $=\underline{451} \times 100$ resep $=39$ resep 1145

3. Bulan Juni 2018 ada 320 lembar resep, maka diperoleh sampel sebanyak $=\underline{320} \times 100$ resep $=27$ resep. 1145

Instrumen penelitian berupa lembar dokumen yang memuat data resep obat pasien BPJS poliklinik penyakit dalam RSD Idaman Banjarbaru. Pengolahan data-data penelitian dilakukan dengan menghitung persentase kesesuaian peresepan obat BPJS dengan formularium nasional dan formularium rumah sakit dengan rumus sebagai berikut:

1. Persentase kesesuaian resep BPJS dengan Formularium Nasional

$\%$ sesuai $=$ jumlah resep sesuai FN $\times 100 \%$ Jumlah semua resep

$\%$ tak sesuai=jumlah resep non FN $\times 100 \%$ Jumlah semua resep

2. Persentase kesesuaian resep BPJS dengan Formularium Rumah Sakit \%sesuai=jumlah resep sesuai FRS $\times 100 \%$ Jumlah semua resep

\%tak sesuai =jumlah resep non FRS x 100\% Jumlah semua resep
Keterangan :

FN : Formularium Nasional

FRS: Formularium Rumah Sakit

\section{HASIL DAN PEMBAHASAN}

\section{a. Kesesuaian Peresepan Obat BPJS dengan Formularium Nasional}

Hasil penelitian yang telah dilakukan peneliti di instalasi farmasi Rumah Sakit Daerah Idaman Banjarbaru berkenaan dengan kesesuaian resep pasien BPJS di Poliklinik Penyakit Dalam periode bulan April sampai Juni 2018 dapat dilihat pada tabel 1 .

\section{Tabel 1. Data Persentase Kesesuaian Peresepan Obat BPJS dengan Formularium Nasional (FN)}

\begin{tabular}{|c|c|c|c|c|c|}
\hline \multirow{3}{*}{$\begin{array}{l}\text { Bulan } \\
\text { Pene } \\
\text { litian }\end{array}$} & \multirow{3}{*}{$\begin{array}{l}\text { Jum } \\
\text { lah } \\
\text { Re- } \\
\text { sep }\end{array}$} & \multicolumn{4}{|c|}{ Formularium Nasional } \\
\hline & & Sesuai & $\%$ & Tak & $\%$ \\
\hline & & & & $\begin{array}{l}\text { Sesu } \\
\text { ai }\end{array}$ & \\
\hline April & 34 & 24 & 70,6 & 10 & 29,4 \\
\hline Mei & 39 & 25 & 64,1 & 14 & 35,9 \\
\hline Juni & 27 & 19 & 70,4 & 8 & 29,6 \\
\hline & 100 & 68 & 68,4 & 32 & 31,6 \\
\hline
\end{tabular}

Berdasarkan Tabel 1 diatas dapat diketahui bahwa dari 100 lembar sampel resep yang digunakan terdiri dari 34 lembar resep di bulan april, 39 lembar resep di bulan mei dan 27 lembar resep bulan juni 2018, diperoleh hasil kesesuaian obat BPJS dengan Formularium Nasional pada bulan april sebanyak 24 lembar resep, bulan mei sebanyak 25 lembar resep dan bulan juni sebanyak 19 lembar resep sehingga didapatkan jumlah resep yang sesuai dengan formularium nasional sebanyak 68 lembar resep.

Tabel 1 diatas juga menunjukkan persentase kesesuaian obat BPJS dengan Formularium Nasional pada bulan April adalah 70,59\%, bulan Mei 64,10\% dan bulan Juni 2018 adalah $70,37 \%$, sehingga diperoleh rata-rata sebesar $68,35 \%$. Hal ini tidak terlalu jauh berbeda dengan penelitian Hiliyanti, tahun $2015^{8}$ di rumah sakit yang sama yang menyebutkan 
bahwa kesesuaian peresepan obat BPJS dengan formularium nasional sebesar $84,14 \%$.

Hasil penelitian menunjukkan bahwa kesesuaian peresepan obat BPJS berdasarkan formularium nasional di poliklinik penyakit dalam Rumah Sakit Daerah Idaman Banjarbaru masih belum maksimal, dimana untuk standar pelayanan minimal (SPM) kefarmasian tentang kesesuaian peresepan obat berdasarkan formularium adalah $100 \%$, hal ini disebabkan karena terdapat beberapa orang dokter spesialis penyakit dalam yang mempunyai pola peresepan obat yang berbeda-beda tergantung pada protokol terapi masing-masing dokter. ${ }^{8,9}$

Berdasarkan Tabel 1 tersebut juga memperlihatkan ketidaksesuaian peresepan obat BPJS dengan formularium nasional pada bulan april sebanyak 10 lembar resep dengan persentase sebesar $29,42 \%$, bula mei sebanyak 14 lembar resep dengan persentase sebesar $35,90 \%$ dan bulan juni sebanyak 8 lembar resep dengan persentase sebesar $29,63 \%$ sehingga diperoleh jumlah ketidaksesuaian dengan formularium nasional sebanyak 32 lembar resep dengan persentase sebesar $31,65 \%$.

Berdasarkan hasil penelitian ditemukan bahwa terdapat 10 item obat yang tidak sesuai dengan formularium nasional tetapi dituliskan oleh penulis resep di poliklinik penyakit dalam Rumah Sakit Daerah Idaman Banjarbaru, Obat-obatan tersebut diantaranya Neurodex dan Axtan, di mana. Neurodex dan Axtan ini termasuk dalam kategori terapi vitamin sedangkan pada formularium nasional untuk terapi vitamin tersedia dengan zat aktif tunggal, seperti vitamin $B 1$, vitamin $B 6$, dan vitamin B12, penulis resep sering meresepkan vitamin dengan zat aktif kombinasi seperti Neurodex untuk memudahkan pasien meminum obatnya. Akan tetapi Neurodex ini masuk dalam formularium rumah sakit sehingga untuk mendapatkan obat tersebut pasien tidak perlu harus ke luar rumah sakit karena sudah tersedia di instalasi farmasi.

Obat-obatan yang tidak masuk formularium nasional lainnya seperti Novorapid dan Novomix dimana di dalam formularium nasional sediaan yang disiapkan adalah nama generiknya, sedangkan di Pedagang Besar Farmasi (PBF) tidak tersedia, dalam hal ini rumah sakit daerah idaman banjarbaru membuat kebijakan dengan mengambil obat dengan nama dagang untuk memenuhi kebutuhan pasien akan obat tersebut, sehingga dapat meningkatkan pelayanan kefarmasian di Rumah Sakit Daerah Idaman Banjarbaru.

\section{b. Kesesuaian Peresepan Obat BPJS dengan} Formularium Rumah Sakit

Hasil penelitian yang telah dilakukan peneliti pada instalasi farmasi Rumah Sakit Daerah Idaman Banjarbaru berkenaan dengan kesesuaian peresepanobat BPJS dengan Formularium Rumah Sakit di poliklinik penyakit dalam periode bulan April sampai Juni 2018 dapat dilihat pada Tabel 2 berikut.

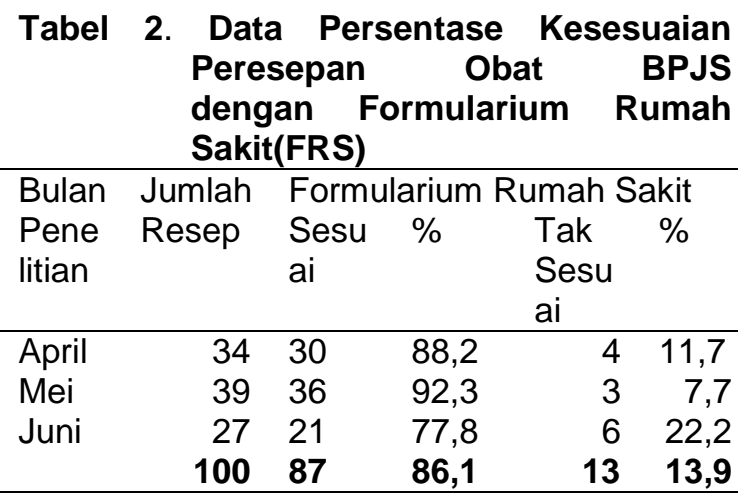

Berdasarkan Tabel 2 diatas menunjukkan bahwa dari sampel 100 lembar resep yang digunakan terdiri dari 34 resep di bulan april, 39 resep di bulan mei dan 27 resep di bulan juni, sesuai proporsi dan dapat mewakili populasinya, diperoleh hasil bahwa resep yang sesuai formularium rumah sakit pada bulan april sebanyak 30 lembar resep, bulan mei sebanyak 36 lembar resep dan bulan juni sebanyak 21 lembar resep, sehingga didapatkan jumlah resep yang sesuai formularium rumah sakit sebanyak 87 lembar resep.Berdasarkan Tabel 2 diatas diperoleh persentase kesesuaian obat BPJS dengan formularium rumah sakit pada bulan april sebesar $88,24 \%$, bulan mei $92,31 \%$ dan bulan juni sebesar $77,78 \%$ sehingga didapatkan rata-rata sebesar $86,11 \%$. Persentase ini menunjukkan bahwa kesesuaian obat BPJS dengan formularium rumah sakit di Rumah 
Sakit Daerah Idaman Banjarbaru sudah cukup tinggi, di mana hal ini dipengaruhi oleh pengetahuan para penulis resep tentang obatobatan yang masuk formularium rumah sakit.

Berdasarkan Tabel 2 juga dapat dilihat bahwa ketidaksesuaian peresepan obat BPJS dengan formularium rumah sakit pada bulan april sebanyak 4 lembar resep dengan persentase sebesar $11,76 \%$, bulan mei sebanyak 3 lembar resep dengan persentase sebesar $7,69 \%$ dan bulan juni sebanyak 6 lembar resep dengan persentase $22,22 \%$ sehingga diperoleh jumlah ketidaksesuaian peresepan obat BPJS dengan formularium rumah sakit sebanyak 13 lembar resep dengan persentase rata-rata sebesar $13,89 \%$.Nama obat yang tidak sesuai dengan formularium rumah sakit adalah curcuma Curcuma tidak terdaftar dalam Formularium Nasional maupun Formularium Rumah Sakit namun penulis resep sering menuliskan obat ini pada pengobatan pasien BPJS terutama untuk pasien baru sembuh yang melakukan kontrol setelah rawat inap. 12,13

Penulis resep beranggapan bahwa Curcuma dapat dengan cepat memulihkan kesehatan pasien pasca rawat inap karena mengandung zat yang dapat meningkatkan nafsu makan pasien. Pasien terpaksa menebus obat tersebut ke luar rumah sakit, diharapkan kepada komite farmasi dan terapi (KFT) untuk menambahkan obat tersebut ke dalam Formularium Rumah Sakit untuk mempermudah pasien mendapatkan obatnya.

\section{SIMPULAN}

Persentase kesesuaian peresepan obat pasien BPJS Kesehatan berdasarkan Formularium Nasional dan Formularium Rumah Sakitpada poliklinik penyakit dalam Rumah Sakit Daerah Idaman Banjarbaru periode April sampai Juni 2018dari sampel 100 lembar resep didapatkan 68 lembar resep yang sesuai Formularium Nasional sebanyak $68,35 \%$ dan yang sesuai Formularium Rumah Sakit 87 lembar resep sebanyak $86,11 \%$.

\section{DAFTAR PUSTAKA}

1. Amirin, T. 2011. Populasi dan Sampel Penelitian 4: Ukuran Sampel Rumus Slovin. Erlangga. Jakarta.

2. Anonim, 2016, Peraturan Menteri Kesehatan Republik Indonesia Nomor 72 Tahun 2016Tentang Starndar Pelayanan Kefarmasian di Rumah Sakit, Depkes RI, Jakarta.

3. Anonim, 2017, Buku Profil Rumah Sakit Daerah Idaman Banjarbaru. Diklat Rumah Sakit Daerah Idaman Banjarbaru.

4. BPJS Kesehatan, 2014, Peraturan Badan Penyelenggara Jaminan Sosial Kesehatan Nomor 3 tahun 2014,tentangTata Cara dan Mekanisme Kerja Pengawasan dan Pemeriksaan Atas Kepatuhan Dalam Penyelenggaraan Program Jaminan Ksehatan, BPJS Kesehatan, Jakarta.

5. 2011, Undang-Undang Nomor 24 Tahun 2011 tentang Badan Penyelenggara Jaminan Sosial. Lembaran Negara Republik Indonesia Tahun 2011, Nomor 116. Jakarta.

6. BSN, 2006, Pedoman Standardisasi Nasional, Edisi 305, Badan Standardisasi Nasional, Jakarta.

7. Fitriah, R. 2019. Evaluasi Kerasionalan Penggunaan Obat Dengan Standar Pelayanan Medis Sebagai Pengendali Pada Penyakit Low Back Pain. Jurnal Insan Farmasi Indonesia, 2(1) 44-53.

8. Joenoes, N.Z., 2011, Ars Prescribensi Resep Yang RasionalEdisi kedua Cetakan Keempat, Airlangga University Press, Surabaya.

9. Hiliyanti, 2015. Kesesuaian Peresepan Obat Pasien BPJS Kesehatan dengan Formularium Nasional Di RSUD Banjarbaru Periode Oktober sampai Desember 2015. KTI Akademi Farmasi ISFI,Banjarmasin.

10. Kemenkes, 2004, Undang-Undang Nomor 40 Tahun 2004 tentang Sistem Jaminan Sosial Nasional.Lembaran Negara Republik Indonesia Tahun 2004, Jakarta.

11. , 2017, Keputusan Menteri Kesehatan Republik Indonesia Nomor HK. 01.07/Menkes//659/2017 tentang Formularium Nasional, Kementrian Kesehatan Republik Indonesia, Jakarta. 
12. Syamsuni, H. A., 2007, IImu ResepCetakan Pertama, EGC, Jakarta.

13. Tanner, Angela Erlitha., Ranti L., Lolo Widya Astuty., 2014, Evaluasi Pelaksanaan Pelayanan Resep Obat Generik pada Pasien BPJS Rawat Jalan di RSUP. PROF.DR.R.D. Kandou Manado periode Januari-Juni 2014. Jurnal IImiah Farmasi - UNSRAT Vol. 4 No. 4 November 2015. 